\title{
Cost-effectiveness of biological treatment of ulcerative colitis - a systematic review
}

\author{
Ewa Stawowczyk ${ }^{1}$, Paweł Kawalec ${ }^{2}$ \\ ${ }^{1}$ StatSoft Polska Sp. z o.o., Krakow, Poland \\ ${ }^{2}$ Drug Management Department, Institute of Public Health, Faculty of Health Sciences, Jagiellonian University Medical College, \\ Krakow, Poland
}

Gastroenterology Rev 2017; 12 (2): 90-97

DOI: https://doi.org/10.5114/pg.2017.68166

Key words: systematic review, cost-effectiveness, ulcerative colitis, economic analysis.

Address for correspondence: Paweł Kawalec MD, PhD, Institute of Public Health, Jagiellonian University Medical College,

20 Grzegórzecka St, 31-531 Krakow, Poland, e-mail: pawel.kawalec@uj.edu.pl

\begin{abstract}
The aim of this systematic review was to collect and summarise all current data on the cost-effectiveness of biological treatment in ulcerative colitis. A literature search was conducted using the Medline, Embase, Centre for Reviews and Dissemination databases and included all cost-effectiveness analyses comparing biological treatment with any comparator. We identified 277 records of which 10 were included in this review. Eighty percent of identified analyses used quality-adjusted life years (QALY) as a measure of outcome. The most commonly assessed biological agent was infliximab. Half of the eight economic analyses, with QALY as an outcome, showed the cost-effectiveness of biological treatment against the comparator. Incremental cost-effectiveness ratios (ICER) ranged from 15,748 euro to 450,791 euro. The highest ICER values were observed when biologicals were compared with standard care alone. This systematic review revealed that in some cases the biological treatment, despite its clinical effectiveness, is too expensive and exceeds the national threshold value.
\end{abstract}

\section{Introduction}

Ulcerative colitis (UC) is an idiopathic inflammatory bowel disease characterised by an inflammatory reaction involving the colonic mucosa [1]. The clinical course is unpredictable and marked by alternating periods of exacerbation and remission, which may occur spontaneously or in response to treatment changes or intercurrent illnesses [2, 3]. Patients with UC have a normal life expectancy [1]. The prevalence rate of UC in North America and northern Europe varies from 156 to 291 cases per 100,000 people [4].

The therapy of UC is directed at a rapid resolution of symptoms, and subsequently maintenance of symptom-free periods. Lifelong medical treatment and often surgery are required. Conventional therapy comprises corticosteroids, aminosalicylates, and drugs that affect the immune response. Ulcerative colitis has a significant impact on quality of life and daily activity, because patients experience loss of energy, negative self-image, and social fear [3].

Until recently, surgery was the only remaining choice for patients with moderate-to-severe chronic UC, in whom the standard treatment failed or was not tolerated. The introduction of biological drugs, such as infliximab, adalimumab, or golimumab, which inhibit tumour necrosis factor $\alpha$ (TNF- $\alpha$ ), has provided a new alternative for the management of UC and is expected to decrease the rate of colectomies or at least extend the time to surgery, compared with standard treatment.

Tumour necrosis factor $\alpha$ is a proinflammatory cytokine found at increased concentrations in the blood, colonic tissue, and stools of patients with UC. Infliximab, adalimumab, and golimumab are chimeric or human monoclonal antibodies that bind with high affinity and specificity to human TNF, neutralising its biological activity [5-7]. On the one hand, their superior efficacy compared with placebo in moderate-to-severe non-acute UC has been well established by clinical trials [8-13]. On the other hand, the use of biologicals constitutes a heavy burden for the public payer, so it can be limited in many countries. It was also expected that the introduction of biologicals to the treatment of inflammatory bowel diseases would cause a substantial 
decline in colectomy rates. However, this issue is equivocal and is still under study.

Economic analyses are performed to assess the cost-effectiveness of the new treatment compared with the existing one (comparator). When an additional clinical effect of the new treatment is proven after comparing it with the existing treatment in a randomised control trial, a cost-effectiveness analysis (CEA) or cost-utility analysis (CUA) is carried out. The CEA considers both the costs of therapy and clinical outcomes, while the CUA additionally includes the quality of life in the form of utility weights. The results are presented in the form of life-years gained or quality-adjusted lifeyears (QALY) gained (when utility weights are included), total costs of therapy including the pharmacotherapy costs, and incremental cost-effectiveness ratio (ICER) or incremental cost-utility ratio (ICUR). The ICER or ICUR values are calculated as the quotient of the difference in costs and the difference in effectiveness between the new therapy and the comparator. The new therapy is deemed cost-effective if it is more effective than the comparator, and the ICER or ICUR value is below the threshold value (in Poland it equals three times the gross domestic product per capita, i.e. 125,955 PLN, about 29,000 EUR or 33,000 USD, as of 2016) [14, 15].

When the same clinical effectiveness of the new therapy and the comparator is proven, based on results of a randomised controlled trial, a cost-minimisation analysis (CMA) is performed. The CMA compares the costs of the new therapy and the comparator, and it does not include the clinical effectiveness because it assumes the same clinical effect and safety profile for the new therapy and the comparator. The results of the CMA are presented as the difference between the new treatment total costs and the comparator total costs. If this difference is negative (below zero), it means that the application of the new therapy instead of the comparator generates savings to the payer [14].

The costs in economic analysis are categorised into two types: direct or indirect. The direct costs include costs directly connected with the treatment, i.e. costs of pharmacotherapy, medical devices, diet supplements, hospitalisations, diagnostic procedures, laboratory tests, and ambulatory care. The indirect costs or productivity losses are the labour earnings that are forgone because of an adverse health outcome, i.e. illness, death, side effects, or time spent on treatment. The productivity losses can occur in paid work, but also in unpaid work, such as household work, care work, or volunteer work [16]. Economic analyses are used during the reimbursement process because they provide valuable information for decision makers and enable them to allocate the limited funds reasonably. Generally, economic analyses are car- ried out from the public payer's perspective (direct costs incurred by public payer are included), the patients' perspective (direct costs incurred by patients are included), or the social perspective (direct and indirect costs are included). The discounting is used in economic analysis with a time horizon longer than one year, to calculate the actual values of costs and outcomes that are likely to occur in the future.

\section{Aim}

The aim of this systematic review was to collect and summarise all data concerning the cost-effectiveness of biological treatment in UC. We focused on four biologicals: infliximab, adalimumab, golimumab, and vedolizumab. Their additional clinical effect has been proven in randomised clinical trials when compared with standard care alone [8-13]. We focused on analyses that compared the biological treatment (alone or with standard care) with any other comparator, i.e. placebo, standard care, surgery, cyclosporine, or another biological agent. We also compared the methodologies of identified analyses.

\section{Material and methods}

\section{Literature search}

To collect data on the cost-effectiveness of biological treatment of UC we performed a systematic review of the literature on 23 August 2016, using the following databases: Centre for Reviews and Dissemination (CRD), MEDLINE (via PubMed), and Embase. In the search we used the following terms: ulcerative colitis, ulcerative disease, and colitis ulcerosa, in order to determine the population; the terms: tumor necrosis factor, tumour necrosis factor, tnf, biologic, infliximab, remicade, inflectra, remsima, adalimumab, humira, golimumab, simponi, vedolizumab, and entyvio, in order to determine intervention; and the terms: cost effectiveness, cost efficacy, cost utility, economic evaluation, economic assessment, and economic analysis in order to determine endpoints. We used a Population, Intervention, Comparison, Outcome (PICO) scheme to describe the population of interest: $\mathrm{P}$ - people affected by UC, we also considered studies conducted in subpopulations; I - we considered biological treatment with infliximab, adalimumab, golimumab, vedolizumab; $C$ - not applicable, we considered all possible alternative treatments for UC; and $\mathrm{O}-$ cost-effectiveness analysis.

The systematic review was performed independently by two different researchers, giving the same results. In case of differences, the authors had to get a consensus on the decision if the specific record should be eligible. All (if any) problematic studies included in this systematic review are marked. 


\section{Study selection}

No date or country filters were used. We included papers written in English. We considered original studies that were primary sources of information about the cost-effectiveness of biologicals in UC, and systematic reviews that were secondary sources leading (by hand-searching) to previously undiscovered cost-effectiveness assessments. We did not include conference abstracts, posters, or health technology assessments (HTAs). Records were excluded if they involved a different intervention (i.e. surgery, pharmacotherapy other than biologics), different endpoints (i.e. clinical analysis, budget impact analysis, cost assessments), or different population (Crohn's disease, inflammatory bowel diseases other than UC). The selected articles that met the inclusion criteria, in accordance with the PICO scheme, were included in this review. The records were selected in accordance with the Preferred Reporting Items for Systematic Reviews and Meta-Analyses (PRISMA) statement.

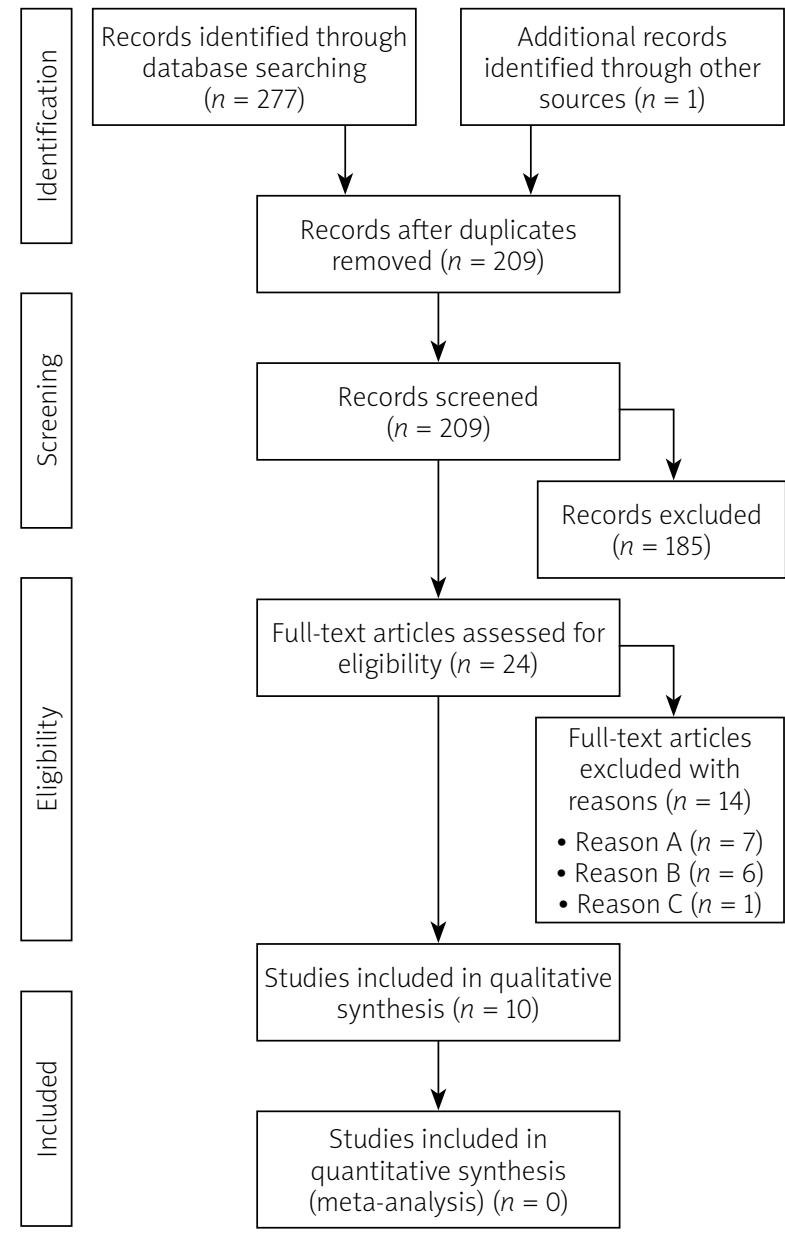

Figure 1. PRISMA flow diagram showing the record selection process. Reason A - secondary data; reason $\mathrm{B}$ - different type of publication; reason $\mathrm{C}$ - different endpoint

\section{Data extraction and presentation}

Data from eligible articles were collected. Based on the Cochrane Handbook for Systematic Reviews of Intervention [17], the following items were collected: first author's name, year of study, population, interventions and comparators, study design (type of economic analysis, perspective, time horizon, methods of measuring outcomes, country, discount rates, currency, cost reference date), and results (total costs, total outcomes, ICER value, conclusions concerning cost-effectiveness). To facilitate the comparison of results, all costs were converted into values from the year 2015, using the consumer price index - a standard and common approach for adjusting costs to a specific year. All cost values were presented in euros (exchange rates as of 8 September 2016). All calculations and data collection were performed using Microsoft Excel (Microsoft Corporation, Redmond, WA).

\section{Data synthesis}

The results of the identified analyses were grouped according to the type of biologicals: infliximab, adalimumab, golimumab, and vedolizumab, as well as according to the type of measured outcomes. The cost-effectiveness was assessed based on conclusions from each study (the ICER value compared with the threshold value in a particular country). A quantitative analysis was not possible because there were significant differences in study designs, interventions, and populations.

\section{Results}

The systematic search identified 277 references. After removing duplicates, 209 records were left and submitted for further assessment based on their abstracts. Out of these, 24 records were analysed based on full texts. Next, 14 records were excluded due to secondary data (systematic reviews), different type of publication (HTA reports, conference abstracts), or different endpoints. The remaining 10 records were included in this review (Figure 1).

Out of 10 identified economic evaluations, three used decision-tree modelling [18-20] and seven were based on Markov modelling [21-27]. QALY was the endpoint of eight analyses [18, 19, 21-23, 25-27], remission and response was used in one study [24], and mucosal healing in another one [20]. The most commonly assessed biological agent was infliximab - eight studies [18-20, 23-27]. Adalimumab was included in four economic evaluations [20, 21, 24, 27], golimumab in two [22, 24], while only one analysis was found for vedolizumab [20]. The comparators included for biological agents were: standard/usual care/conventional therapy [19, 21-27], cyclosporine [18, 19], surgical 
treatment $[18,19]$, and another biological agent [20, 24]. The time horizon varied from 1 year $[18,19,20$, $24]$, through five $[26,27]$ and 10 years $[25,26]$, to 30 years [21-23]. Table I presents the characteristics of the included studies.

Among eight economic evaluations with QALY as an endpoint, four demonstrated the cost-effectiveness of the biological agent compared with alternative treatment $[18,19,25,26]$. The ICERs (cost per one additional QALY) for the biologicals ranged from 15,748 EUR to 450,791 EUR (Table II).
Infliximab, when compared with standard care alone, resulted in an ICER value ranging from about 29,000 EUR to 93,000 EUR - only two studies were identified, and the lower ICER value was obtained in the study where only patients in remission were included. The ICER values were lower when infliximab was compared with cyclosporine (from 24,000 to 26,000 EUR) or surgical treatment (16,000 EUR). A biological treatment combining infliximab and adalimumab (as a second-line treatment) compared with standard care resulted in an ICER value of 280,000 EUR, and it was even higher for

Table I. Characteristics of the included studies

\begin{tabular}{|c|c|c|c|}
\hline Reference & Population & $\begin{array}{l}\text { Intervention and } \\
\text { comparators }\end{array}$ & Study design/methods \\
\hline $\begin{array}{l}\text { Chaudhary, } \\
2013[18]\end{array}$ & $\begin{array}{l}\text { Sever UC adult patients } \\
\text { hospitalized with } \\
\text { an acute exacerbation } \\
\text { of the disease }\end{array}$ & $\begin{array}{l}\text { Infliximab, cyclosporine, } \\
\text { surgical intervention }\end{array}$ & $\begin{array}{l}\text { Type: CEA, decision-tree; perspective: national payer; horizon: } \\
1 \text { year; methods of measuring outcomes: QALY; country: } \\
\text { Netherlands; discount rates: costs } 4 \% \text {, effects 1.5\%; currency: } \\
\text { euro; cost reference date: } 2010\end{array}$ \\
\hline $\begin{array}{l}\text { Punekar, } \\
2010[19]\end{array}$ & $\begin{array}{l}\text { Moderate/severe UC } \\
\text { patients hospitalized with } \\
\text { an acute exacerbation of } \\
\text { the disease }\end{array}$ & $\begin{array}{l}\text { Standard care, infliximab, } \\
\text { cyclosporine, surgery }\end{array}$ & $\begin{array}{l}\text { Type: CEA, decision-tree; perspective: public payer; horizon: } \\
1 \text { year; methods of measuring outcomes: QALY; country: } \\
\text { England and Wales; discount rates: costs 3.5\%, effects 3.5\%; } \\
\text { currency: GBP; cost reference date: } 2006-2007\end{array}$ \\
\hline $\begin{array}{l}\text { Stawowczyk, } \\
2016[21]\end{array}$ & $\begin{array}{l}\text { Moderate/severe UC } \\
\text { patients, induction and } \\
\text { maintenance treatment }\end{array}$ & $\begin{array}{l}\text { Adalimumab + standard } \\
\text { care, standard care }\end{array}$ & $\begin{array}{l}\text { Type: CEA, Markov; perspective: public payer, social; horizon: } \\
30 \text { years; methods of measuring outcomes: QALY; country: } \\
\text { Poland; discount rates: costs 5\%, effects 3.5\%; currency: euro; } \\
\text { cost reference date: } 2015\end{array}$ \\
\hline $\begin{array}{l}\text { Stawowczyk, } \\
2016[22]\end{array}$ & $\begin{array}{l}\text { Moderate/severe UC } \\
\text { patients, induction and } \\
\text { maintenance treatment }\end{array}$ & $\begin{array}{l}\text { Golimumab + standard } \\
\text { care, standard care }\end{array}$ & $\begin{array}{l}\text { Type: CEA, Markov; perspective: public payer, social; horizon: } \\
30 \text { years; methods of measuring outcomes: QALY; country: } \\
\text { Poland; discount rates: costs 5\%, effects 3.5\%; currency: PLN; } \\
\text { cost reference date: } 2015\end{array}$ \\
\hline $\begin{array}{l}\text { Stawowczyk, } \\
2016[23]\end{array}$ & $\begin{array}{l}\text { Moderate/severe UC } \\
\text { patients, induction and } \\
\text { maintenance treatment }\end{array}$ & $\begin{array}{l}\text { Infliximab + standard } \\
\text { care, standard care }\end{array}$ & $\begin{array}{c}\text { Type: CEA, Markov; perspective: public payer; horizon: } \\
30 \text { years; methods of measuring outcomes: QALY; country: } \\
\text { Poland; discount rates: costs 5\%, effects 3.5\%; currency: PLN; } \\
\text { cost reference date: } 2015\end{array}$ \\
\hline $\begin{array}{l}\text { Toor, } \\
2015[24]\end{array}$ & $\begin{array}{l}\text { Moderate/severe UC } \\
\text { patients, induction and } \\
\text { maintenance treatment }\end{array}$ & $\begin{array}{l}\text { Conventional therapy, } \\
\text { infliximab, adalimumab, } \\
\text { golimumab } 50 \mathrm{mg} \text {, } \\
\text { golimumab } 100 \mathrm{mg}\end{array}$ & $\begin{array}{l}\text { Type: CEA, Markov; perspective: public payer; horizon: } 1 \text { year; } \\
\text { methods of measuring outcomes: response, remission; country: } \\
\text { Canada; discount rates: no; currency: SCAD; cost reference } \\
\text { date: } 2013\end{array}$ \\
\hline $\begin{array}{l}\text { Tsai, } \\
2008[25]\end{array}$ & $\begin{array}{c}\text { Moderate/severe UC } \\
\text { patients, scheduled } \\
\text { maintenance treatment }\end{array}$ & $\begin{array}{l}\text { Infliximab + standard } \\
\text { care, standard care }\end{array}$ & $\begin{array}{l}\text { Type: CEA, Markov; perspective: public payer; horizon: } 10 \text { years; } \\
\text { methods of measuring outcomes: QALY; country: England and } \\
\text { Wales; discount rates: costs 3.5\%, effects 3.5\%; currency: GBP; } \\
\text { cost reference date: } 2006-2007\end{array}$ \\
\hline $\begin{array}{l}\text { Ung, } \\
2014 \text { [26] }\end{array}$ & $\begin{array}{l}\text { Moderate/moderately } \\
\text { severe UC patients, } \\
\text { induction and } \\
\text { maintenance treatment }\end{array}$ & $\begin{array}{l}\text { Infliximab + standard } \\
\text { care, standard care }\end{array}$ & $\begin{array}{l}\text { Type: CEA, Markov; perspective: health system; horizon: } 5 \text { and } \\
10 \text { years; methods of measuring outcomes: QALY, real-life data; } \\
\text { country: Canada; discount rates: costs 5\%, effects 5\%; currency: } \\
\text { USD; cost reference date: } 2013\end{array}$ \\
\hline $\begin{array}{l}\text { Xie, } \\
2009[27]\end{array}$ & $\begin{array}{l}\text { Moderate-to-severe } \\
\text { refractory UC patients, } \\
\text { induction and } \\
\text { maintenance treatment }\end{array}$ & $\begin{array}{l}\quad \text { Infliximab } 5 \mathrm{mg} \text {, } \\
\text { adalimumab, infliximab } \\
5 \mathrm{mg} \text {, infliximab } 10 \mathrm{mg} \text {, } \\
\quad \text { usual care }\end{array}$ & $\begin{array}{l}\text { Type: CEA, Markov; perspective: public payer; horizon: } 5 \text { years; } \\
\text { methods of measuring outcomes: QALY; country: Canada; } \\
\text { discount rates: costs } 5 \% \text {, effects } 5 \% \text {; currency: CAD; cost } \\
\text { reference date: } 2008\end{array}$ \\
\hline $\begin{array}{l}\text { Yokomizo, } \\
2016[20]\end{array}$ & $\begin{array}{l}\text { Moderate-to-severe UC } \\
\text { patients, induction and } \\
\text { maintenance treatment }\end{array}$ & $\begin{array}{l}\text { Infliximab } 5 \text { mg, } \\
\text { infliximab } 10 \mathrm{mg} \\
\text { adalimumab, } \\
\text { vedolizumab }\end{array}$ & $\begin{array}{l}\text { Type: CEA, decision tree; perspective: third party's; horizon: } \\
1 \text { year; methods of measuring outcomes: remission, mucosal } \\
\text { healing; country: USA; discount rates: no; currency: USD; cost } \\
\text { reference date: } 2014\end{array}$ \\
\hline
\end{tabular}

UC - ulcerative colitis, CEA - cost-effectiveness analysis, $Q A L Y$ - quality-adjusted life-years. 
Table II. Cost-effectiveness of biologicals for the treatment of ulcerative colitis

\begin{tabular}{|c|c|c|}
\hline Reference & Results - original values & ICER - 2015 euro values \\
\hline $\begin{array}{l}\text { Chaudhary, } \\
2013 \text { [18] }\end{array}$ & $\begin{array}{c}\text { Total costs: IFX }=17,062, \mathrm{CSP}=14,784, \mathrm{~S}=13,979 \\
\text { QALY: IFX }=0.80, \mathrm{CSP}=0.70, \mathrm{~S}=0.58 \\
\text { ICER: IFX vs. CSP }=24,277, \text { IFX vs. } \mathrm{S}=14,639 \\
\text { Conclusion: IFX is cost-effective compared with CSP and S }\end{array}$ & $\begin{array}{l}\text { IFX vs. CSP }=26,117 \\
\text { IFX vs. } S=15,748\end{array}$ \\
\hline $\begin{array}{l}\text { Punekar, } \\
2010 \text { [19] }\end{array}$ & $\begin{array}{c}\text { Total costs: } S=17,067, \mathrm{CSP}=18,122, \mathrm{SC}=18,524, \mathrm{IFX}=19,847 \\
\text { QALY: } \mathrm{S}=0.58, \mathrm{CSP}=0.70, \mathrm{SC}=0.68, \mathrm{IFX}=0.80 \\
\text { ICER: IFX vs. CSP }=19,545 \\
\text { Conclusion: IFX is cost-effective compared with CSP, S, SC }\end{array}$ & IFX vs. CSP $=24,171$ \\
\hline $\begin{array}{l}\text { Stawowczyk, } \\
2016[21]\end{array}$ & $\begin{array}{l}\text { Total costs, public payer: } \mathrm{ADA}=20,598, \mathrm{SC}=9950 \\
\text { Total costs, social: } \mathrm{ADA}=93,765, \mathrm{SC}=83,770 \\
\text { QALY: } \mathrm{ADA}=15.204, \mathrm{SC}=15.064 \\
\text { ICER public payer: } \mathrm{ADA} \text { vs. } \mathrm{SC}=76,120 \\
\text { ICER social: } \text { ADA vs. } \mathrm{SC}=71,457 \\
\text { Conclusion: ADA is not cost-effective compared with SC }\end{array}$ & $\begin{array}{l}\text { Public payer perspective: } \\
\text { ADA vs. } \mathrm{SC}=76,120 \\
\text { Social perspective: } \\
\text { ADA vs. } S C=71,457\end{array}$ \\
\hline $\begin{array}{l}\text { Stawowczyk, } \\
2016[22]\end{array}$ & $\begin{array}{c}\text { Total costs, public payer: } \mathrm{GOL}=93,321, \mathrm{SC}=45,502 \\
\text { Total costs, social: } \mathrm{GOL}=302,848, \mathrm{SC}=257,092 \\
\text { QALY: } \mathrm{GOL}=19.241, \mathrm{SC}=19.118 \\
\text { ICER public payer } \mathrm{GOL} \text { vs. } \mathrm{SC}=391,252 \\
\text { ICER social: } \mathrm{GOL} \text { vs. } \mathrm{SC}=374,377 \\
\text { Conclusion: } \mathrm{GOL} \text { is not cost-effective compared with SC }\end{array}$ & $\begin{array}{l}\text { Public payer perspective: } \\
\text { GOL vs. SC }=90,757 \\
\text { Social perspective: } \\
\text { GOL vs. SC }=86,842\end{array}$ \\
\hline $\begin{array}{l}\text { Stawowczyk, } \\
2016[23]\end{array}$ & $\begin{array}{c}\text { Total costs: IFX }=99,522, \mathrm{SC}=29,642 \\
\text { QALY: IFX }=14.296, \mathrm{SC}=14.123 \\
\text { ICER: IFX vs. SC }=402,420 \\
\text { Conclusion: IFX is not cost-effective compared with SC }\end{array}$ & IFX vs. SC $=93,347$ \\
\hline $\begin{array}{l}\text { Toor, } \\
2015[24]\end{array}$ & $\begin{array}{l}\text { Cost per } 1 \text { year additional remission / response: GOL } 50 \text { vs. } \\
\text { SC = 1048/770, GOL } 100 \text { vs. SC }=935 / 701, \text { IFX vs. SC }=1975 / 1311 \text {, } \\
\text { ADA vs. SC = 7,430/2361, IFX vs. GOL } 100=14,659 / 4753, \\
\text { ADA vs. GOL } 100=-3324 /-4019 \\
\text { Conclusions: GOL } 100 \text { and GOL } 50 \text { have the lowest cost of additional } \\
1 \text { year of remission and response; IFX has the highest efficacy, but also } \\
\text { high costs, ADA produced the highest cost/remission and response }\end{array}$ & $\begin{array}{l}\text { Cost per } 1 \text { year additional remission/response: } \\
\text { GOL } 50 \text { vs. SC }=758 / 557 \\
\text { GOL } 100 \text { vs. SC }=677 / 507 \\
\text { IFX vs. SC }=1429 / 949 \\
\text { ADA vs. SC }=5377 / 1709 \\
\text { IFX vs. GOL } 100=10,609 / 3440 \\
\text { ADA vs. GOL } 100=-2406 /-2909\end{array}$ \\
\hline $\begin{array}{l}\text { Tsai, } \\
2008[25]\end{array}$ & $\begin{array}{r}\text { Responders only: Total costs: IFX }=66,460, \mathrm{SC}=45,798 \\
\text { QALY: IFX }=4.591, \mathrm{SC}=3.838 \\
\text { ICER: IFX vs. SC }=27,424 \\
\text { Remission only: Total costs: IFX }=53,874, \mathrm{SC}=46,259 \\
\text { QALY: IFX }=4.154, \mathrm{SC}=3.767 \\
\text { ICER: IFX vs. SC }=19,696 \\
\text { Conclusion: IFX is cost-effective compared with SC }\end{array}$ & $\begin{array}{l}\text { Responders only: } \\
\text { IFX vs. SC }=40,065 \\
\text { Remission only: } \\
\text { IFX vs. SC }=28,774\end{array}$ \\
\hline $\begin{array}{l}\text { Ung, } \\
2014[26]\end{array}$ & $\begin{array}{l}\text { ICER: IFX vs. SC = 79,000 ( } 5 \text { years), 64,000 (10 years) } \\
\text { Conclusion: IFX is cost-effective compared with SC }\end{array}$ & IFX vs. SC $=73,085$ (5 years), 59,208 (10 years) \\
\hline $\begin{array}{l}\text { Xie, } \\
2009[27]\end{array}$ & $\begin{array}{c}\text { ICER: IFX ADA vs. SC }=358,088 \text {, IFX IFX vs. SC }=575,540 \\
\text { Conclusion: Anti-TNF- } \alpha \text { therapies are not cost-effective compared } \\
\text { with SC }\end{array}$ & $\begin{array}{l}\text { IFX ADA vs. } S C=280,472 \\
\text { IFX IFX vs. } S C=450,791\end{array}$ \\
\hline $\begin{array}{l}\text { Yokomizo, } \\
2016[20]\end{array}$ & $\begin{array}{l}\text { Cost per } \mathrm{MH} \text { achieved: IFX } 5=99,171, \text { IFX } 10=123,653, \mathrm{ADA}=316,378, \\
\text { VED }=301,969 \\
\text { Cost per } 1 \text { additional MH achieved: IFX } 5 \text { vs. IFX } 10=1,243,310, \\
\text { IFX } 5 \text { vs. ADA - dominated, IFX } 5 \text { vs. VED - dominated } \\
\text { Conclusions: IFX is the most cost-effective treatment option }\end{array}$ & $\begin{array}{l}\text { Cost per } 1 \text { additional } \mathrm{MH} \text { achieved: } \\
\text { IFX } 5 \text { vs. IFX } 10=1,133,201 \\
\text { IFX } 5 \text { vs. ADA - dominated } \\
\text { IFX } 5 \text { vs. VED - dominated }\end{array}$ \\
\hline
\end{tabular}

the treatment combining infliximab at a dose of $5 \mathrm{mg}$ and infliximab at a dose of $10 \mathrm{mg}-451,000$ EUR.

Adalimumab compared with standard care showed an ICER value of about 71,000 to 76,000 EUR, while treatment with golimumab resulted in a higher ICER value of about 87,000 to 91,000 EUR.

If outcomes other than QALY were considered, golimumab at a dose of $100 \mathrm{mg}$ had lower cost per re- 
mission and per response than golimumab at a dose of $50 \mathrm{mg}$, infliximab, and adalimumab. When the cost per mucosal healing achieved was taken into consideration, infliximab at a dose of $5 \mathrm{mg}$ had a lower value than infliximab at a dose of $10 \mathrm{mg}$, adalimumab, and vedolizumab.

Infliximab treatment seems to be a cost-effective treatment option for patients with moderate-to-severe UC when compared to cyclosporine or surgery. The ICER value for infliximab, as well as for adalimumab and golimumab, compared with standard care alone, exceeded the threshold value, but infliximab turned out to be cost-effective when only patients with clinical remission or only patients with response were considered. The highest ICER value was observed when infliximab was used with adalimumab (adalimumab used in all patients after failure of infliximab) or when higher dose of infliximab (10 mg) was used in all patients after failure of infliximab $5 \mathrm{mg}$.

There is a need for further economic evaluations for vedolizumab. This biological agent was assessed only in one cost-effectiveness analysis with remission and mucosal healing as the outcomes, and compared with infliximab.

\section{Discussion}

This review focused on the economic analyses concerning the use of biological agents in UC. We collected and summarised all current data on the cost-effectiveness of infliximab, adalimumab, golimumab, and vedolizumab. The treatment of moderate-to-severe UC patients with biological agents is effective but costly. Despite the high cost of the drug, in some cases this is the only possible and effective way of treatment. The biological agents are used not only to induce remission of the disease or to treat acute exacerbations, but they are also applied in maintenance treatment to prolong the remission-free period. It is recommended to use biologics for as long as the patient responds to treatment, but it generates a huge burden to the public payer.

We included studies concerning different biologicals and comparators, different outcomes (mainly QALY, but also remission, response, and mucosal healing), different perspectives (public payer, social), and different decision models (Markov, decision-tree). The selected economic analyses for biological treatment assessed its cost-effectiveness compared with standard care, cyclosporine treatment, surgical intervention, or another biological agent. Half of the selected studies demonstrated the cost-effectiveness of biologicals. Due to the very diverse methods used in the selected studies, it was impossible to conduct a meta-analysis of the re- sults. The highest number of economic analyses - three - was found for Canada (two out of three used QALY as an outcome and one used remission and response) and Poland (all three used QALY as an outcome). The results of the conducted analyses for biological treatment in Canada were not consistent - one analysis [26] showed that infliximab is a cost-effective treatment option compared with standard care and one [27] proved that anti-TNF- $\alpha$ therapies are not cost-effective compared with standard care. Conclusions for all three economic analyses, conducted for three different biologicals used in Poland, are consistent - infliximab, adalimumab, and golimumab turned out not to be cost-effective compared with standard care alone [21-23].

We found other reviews of the literature concerning the cost-effectiveness of biologicals in UC [28-32]. In her review, Bodger [28] included not only the economic analyses for biological agents, but also for 5-aminosalicylates, oral corticosteroids, and surgery used in UC, and found only one study for infliximab [25], which was also included in our review. The same study was also identified in a review by Di Sabatino et al. [29], who additionally included the HTA report for infliximab, and in a review by Odes and Greenberg [31], who also identified economic analyses made by Tsai et al. [25] and Xie et al. [27]. Huoponen and Blom [30] included in their search the widest range of biological agents used in UC: infliximab, adalimumab, golimumab, certolizumab, natalizumab, and vedolizumab. No studies other than the ones included in our review [18, 19, 25-27] were identified, besides the HTA reports for infliximab and adalimumab (not included in our review due to different inclusion criteria). Xie [32] carried out a systematic review only for adalimumab used in UC and identified two conference abstracts (not included in our review due to different inclusion criteria) and one full-text economic analysis [27], which was included in our review.

The following economic analyses identified in our review were not included in other systematic reviews: Stawowczyk et al. [21], Stawowczyk et al. [22], Stawowczyk et al. [23], Toor et al. [24], and Yokomizo et al. [20].

Our systematic review encompassed the main biological agents that are registered for use in the treatment of UC, i.e. infliximab, adalimumab, vedolizumab, and golimumab. We searched not only Medline but also the Embase and CRD databases, and we did not use any time and language limits. This allowed us to examine data unidentified in previous systematic reviews. The search was conducted in compliance with the PRISMA statement to ensure correct methodology and clarity of the record selection process. We also recalculated costs to euro values as of 2015 to ensure the best comparability. 
The comparison of conclusions concerning the cost-effectiveness in particular studies included in the systematic review is difficult because different threshold values are used in different countries. For example, the threshold value for Poland, which is 125,955 PLN (about 29,000 EUR or 33,000 USD) in the year 2016, is one of the lowest in Europe. Additionally, some countries have special thresholds or reimbursement criteria for innovative drugs. The cost of biological drugs and other costs can vary significantly among countries.

The treatment methods used in selected economic evaluations differed significantly. Some analyses assumed only induction treatment of acute exacerbation, others also included maintenance treatment which is recommended by clinical guidelines. The use of a biological agent after a failure of treatment with another one was rarely included in the economic analyses. Only two $[21,22]$ of the identified economic evaluations included indirect costs of the disease.

\section{Conclusions}

The biological drug that was assessed most often is infliximab, while only one economic analysis, with QALY as an outcome, was found for golimumab and adalimumab as a first-line treatment. There were no studies carried out for vedolizumab. The results of our review demonstrate a need for further cost-effectiveness studies, especially for the biological drugs used in UC.

\section{Conflict of interest}

The authors declare no conflict of interest.

\section{References}

1. Baumgart DC, Sandborn WJ. Inflammatory bowel disease: clinical aspects and established and evolving therapies. Lancet 2007; 369: 1641-57.

2. Kornbluth A, Sachar DB; The Practice Parameters Committee of the American College of Gastroenterology. Ulcerative Colitis Practice Guidelines in Adults: American College of Gastroenterology, Practice Parameters Committee. Am J Gastroenterol 2010; 105: 501-23.

3. Ordás I, Eckmann L, Talamini M, et al. Ulcerative colitis. Lancet 2012; 380: 1606-19.

4. Farrell TJ, Peppercorn MA. Ulcerative colitis. Lancet 2002; 359: 331-40.

5. Summary of Product Characteristic Remsima.

6. Summary of Product Characteristic Humira.

7. Summary of Product Characteristic Simponi.

8. Rutgeerts P, Sandborn WJ, Feagan BG, et al. Infliximab for induction and maintenance therapy for ulcerative colitis. N Engl J Med 2005; 353: 2462-76.

9. Sandborn WJ, van Assche G, Reinish W, et al. Adalimumab induces and maintains clinical remission in patients with moderate-to-severe ulcerative colitis. Gastroenterology 2012; 142: 257-65.
10. Suzuki Y, Motoya S, Hanai H, et al. Efficacy and safety of adalimumab in Japanese patients with moderately to severely active ulcerative colitis. J Gastroenterol 2014; 49: 283-94.

11. Sandborn WJ, Feagan BG, Marano C, et al. Subcutaneous golimumab induces clinical response and remission in patients with moderate-to-severe ulcerative colitis. Gastroenterology 2014; 146: 85-95.

12. Sandborn WJ, Feagan BG, Marano C, et al. Subcutaneous golimumab maintains clinical response in patients with moderate-to-severe ulcerative colitis. Gastroenterology 2014; 146: 96-109.

13. Feagan BG, Rutgeerts P, Sands BE, et al. Vedolizumab as induction and maintenance therapy for ulcerative colitis. N Engl J Med 2013; 369: 699-710.

14. Drummond MF, O’Brien B, Stoddart GL, Torrance GW. Metody badań ekonomicznych programów ochrony zdrowia. Via Medica, Gdansk 2003.

15. Polish Agency for Health Technology Assessment and Tariff System (Agencja Oceny Technologii Medycznych i Taryfikacji, AOTMiT), www.aotm.gov.pl (access: August 2016).

16. Krol M, Brouwer W. How to estimate productivity costs in economic evaluations. Pharmacoeconomics 2014; 32: 335-44.

17. Higgins JPT, Green S (eds.). Cochrane Handbook for Systematic Reviews of Interventions. http://handbook.cochrane.org/ (access: August 2016).

18. Chaudhary MA, Fan T. Cost-effectiveness of infliximab for the treatment of acute exacerbations of ulcerative colitis in the Netherlands. Biol Ther 2013; 3: 45-60.

19. Punekar YS, Hawkins N. Cost-effectiveness of infliximab for the treatment of acute exacerbations of ulcerative colitis. Eur J Health Econ 2010; 11: 67-76.

20. Yokomizo L, Limketkai B, Park KT. Cost-effectiveness of adalimumab, infliximab or vedolizumab as first-line biological therapy in moderate-to-severe ulcerative colitis. BMJ Open Gastro 2016; 3: e000093.

21. Stawowczyk E, Kawalec P, Pilc A. Cost-utility analysis of 1-year treatment with adalimumab/standard care and standard care alone for ulcerative colitis in Poland. Eur J Clin Pharmacol 2016; 72: 1319-25.

22. Stawowczyk E, Kawalec P, Pilc A. Cost-effectiveness analysis of 1-year treatment with golimumab/standard care and standard care alone for ulcerative colitis in Poland. PLoS One 2016; 11 : e0160444.

23. Stawowczyk E. Kawalec P, Pilc A. Cost-utility analysis of infliximab with standard care versus standard care alone for induction and maintenance treatment of patients with ulcerative colitis in Poland. Pharmacotherapy 2016; 36: 472-81.

24. Toor K, Druyts E, Jansen JP, Thorlund K. Cost per remission and cost per response with infliximab, adalimumab, and golimum$\mathrm{ab}$ for the treatment of moderately-to-severely active ulcerative colitis. J Med Econom 2015; 18: 437-46.

25. Tsai HH, Punekar YS, Morris J, Fortun P. A model of the longterm cost effectiveness of scheduled maintenance treatment with infliximab for moderate-to-severe ulcerative colitis. Aliment Pharmacol Ther 2008; 28: 1230-9.

26. Ung V, Thanh NX, Wong K, et al. Real-life treatment paradigms show infliximab is cost-effective for management of ulcerative colitis. Clin Gastroenterol Hepatol 2014; 12: 1871-8. 
27. Xie F, Blackhouse G, Assasi N, et al. Cost-utility analysis of infliximab and adalimumab for refractory ulcerative colitis. Cost Eff Resour Alloc 2009; 11: 7-20.

28. Bodger K. Cost effectiveness of treatments for inflammatory bowel disease. Pharmacoeconomics 2011; 29: 387-401.

29. Di Sabatino A, Liberato L, Marchetti M, et al. Optimal use and cost-effectiveness of biologic therapies in inflammatory bowel disease. Intern Emerg Med 2011; Suppl 1: 17-27.

30. Huoponen S, Blom M. Systematic review of the cost-effectiveness of biologics for the treatment of inflammatory bowel diseases. PLoS One 2015; 10: e0145087.

31. Odes S, Greenberg D. A medicoeconomic review of early intervention with biologic agents in the treatment of inflammatory bowel diseases. Clinicoeconom Outcomes Res 2014; 6: 431-43.

32. Xie F. The economics of adalimumab for ulcerative colitis. Expert Rev Pharmacoeconom Outcomes Res 2015; 15: 373-7.

Received: 24.10 .2016

Accepted: 28.03.2017 